\title{
Early vegetation control for the regeneration of a single-cohort, intimate mixture of white spruce and aspen on upland boreal sites $-10^{\text {th }}$ year update
}

\author{
by Douglas G. Pitt ${ }^{1}$, Philip G. Comeau², William C. Parker³, Michael K. Hoepting ${ }^{4}$, \\ Daniel Maclsaac ${ }^{5}$, Scott McPherson ${ }^{6}$ and Milo Mihajlovich ${ }^{7}$
}

\begin{abstract}
In Canada's boreal forest region, mixedwood stands dominated by trembling aspen (Populus tremuloides Michx.) and white spruce (Picea glauca [Moench] Voss) are prominent and provide important timber and non-timber values. A paucity of silvicultural tools for regenerating mixedwood conditions prompted the establishment of an experiment in 2002, replicated in west-central Alberta and northeastern Ontario, to test a strategy for regenerating a single-cohort, intimate mixture of aspen and white spruce. After ten growing seasons, spruce planted at 5-m spacing, each free of woody and early (first two years) herbaceous competition within a 2-m radius, had equivalent or better survival, height growth and health status than spruce growing competition-free for the duration of the experiment $(\alpha=0.05)$. Select aspen situated in the vicinity of these spruce were at least as large as aspen crop trees situated in undisturbed plots. The year-10 results of this long-term experiment suggest the hypothesized mixedwood regeneration strategy may offer a practical means of establishing mixedwoods capable of producing an early fibre rotation of aspen ( age 30) and long term (> 60years) sawlog crop of spruce.
\end{abstract}

Key words: white spruce; aspen; boreal mixedwood silviculture; vegetation management

\begin{abstract}
RÉSUMÉ
Dans la région de la forêt boréale du Canada, les peuplements mélangés dominés par le peuplier faux-tremble (Populus tremuloides Michx.) et lépinette blanche (Picea glauca [Moench] Voss) sont les plus fréquents et constituent une importante source de matière ligneuse et de valeurs non ligneuses. Labsence doutils sylvicoles adaptés à la régénération des peuplements mélangés a entraîné le démarrage d'un essai en 2002, reproduit dans le centre-ouest de l'Alberta et le nord-est de l'Ontario, afin de tester une stratégie de régénération d'un peuplement formé d'une cohorte unique et étroitement liée de peuplier et dépinette blanche. Après dix années de croissance, les épinettes plantées à $5 \mathrm{~m}$ d'intervalle, chaque semis ayant été libéré de la compétition ligneuse et herbacée hâtive (au cours des deux premières années) dans un rayon de $2 \mathrm{~m}$, affichaient un taux de survie équivalent ou supérieur, ainsi qu’un taux de croissance en hauteur et de santé, aux épinettes libres de croitre au cours de la période de l'essai $(\alpha=0,05)$. Les peupliers sélectionnés à proximité de ces épinettes étaient au moins aussi gros que les peupliers destinés à être récoltés dans les parcelles témoins. Ces résultats après 10 ans de cet essai à long terme démontre que la stratégie proposée de régénération des peuplements mélangés constituerait une mesure pratique détablissement de peuplements mélangés capables de produire une récolte hâtive de fibre de peuplier (vers 30 ans) et à plus long terme (plus de 60 ans) de billots de sciage d'épinette.
\end{abstract}

Mots clés : épinette blanche, tremble, sylviculture des peuplements mélangés boréaux, contrôle de la végétation

\footnotetext{
${ }^{1}$ Corresponding author: Canadian Wood Fibre Centre, Canadian Forest Service, 1219 Queen St. E., Sault Ste. Marie, ON, Canada. P6A 2E5. E-mail: dpitt@NRCan.gc.ca.

${ }^{2}$ University of Alberta, Department of Renewable Resources, 751 General Services Bldg., Edmonton, AB, Canada. T6G 2H1 (pcomeau@ualberta.ca)

${ }^{3}$ Ontario Forest Research Institute, Ontario Ministry of Natural Resources, 1235 Queen Street East, Sault Ste. Marie, ON, Canada. P6A 2 E5. (bill.parker@ontario.ca)

${ }^{4}$ Canadian Wood Fibre Centre, Canadian Forest Service, 1219 Queen St. E., Sault Ste. Marie, ON, Canada. P6A 2 E5. (mhoeptin@NRCan.gc.ca)

${ }^{5}$ Canadian Wood Fibre Centre, Canadian Forest Service, 5320-122 St., Edmonton, AB, Canada. T6H 3S5. (dmacisaac@NRCan.gc.ca)

${ }^{6}$ Science and Information Branch, Ontario Ministry of Natural Resources, 3301 Trout Lake Rd., North Bay, ON, Canada. P1A 4 L7. (scott.mcpherson@ontario.ca)

${ }^{7}$ Incremental Forest Technologies Ltd., 200, 14440-123 Ave., Edmonton, AB, Canada. T5L 2Y3. (Milo.Mihajlovich@gmail.com)
} 


\section{Introduction}

In the boreal forest, mesic upland sites are often highly productive and capable of supporting healthy stands of virtually any of the boreal tree species in relatively pure or mixed compositions. Natural species compositions on these sites are largely a function of time since disturbance, the nature of disturbance, and seed or coppice availability at the time of disturbance (Chen and Popadiouk 2003, Lieffers et al. 2003). Following catastrophic, stand-replacing events such as fire or clearcut logging, species that are rapid colonizers such as trembling aspen (Populus tremuloides Michx.) and pine [lodgepole (Pinus contorta Dougl. ex Loud.) in Canada's west; jack pine (Pinus banksiana Lamb.) east of Alberta] often form pure stands (Greene et al. 1999). Establishment of moderately shade-tolerant white spruce (Picea glauca (Moench) Voss) and black spruce (Picea mariana (Mill.) BSP) may coincide with colonization of these pioneer species, or be delayed for a few decades dependent on the availability of a seed source and suitable microsites for regeneration, giving rise to evenaged or multi-aged mixedwood stands respectively (Cogbill 1985, Peters et al. 2006, Nlungu-Kweta et al. 2014). Over time, canopy openings formed by natural senescence of the shadeintolerant cohort, perhaps hastened by insects, disease and windthrow, encourage the canopy recruitment and further ingress of spruce and balsam fir (Abies balsamea L. (Mill.), gradually converting pure stands to mixedwoods (Chen and Popadiouk 2003, Bergeron et al. 2014). Given enough time between catastrophic events, mixedwoods may eventually succeed to relatively pure spruce stands. Thus a healthy upland boreal landscape will consist of a patchwork mosaic of pure and mixed stands in various stages of succession (Harvey et al. 2002, Bergeron et al. 2014).

It is often the goal of forest management to mimic the species composition and age patterns created by natural disturbances (e.g., OMNR 2001, ESRD 2013). On the upland sites of the boreal forest, clearcutting is widely used to emulate fire in initiating stand renewal (Lieffers and Beck 1994). Following clearcut harvest, aspen frequently regenerates from root suckering with little or no subsequent silvicultural intervention (Lieffers et al. 2003); stocking and density depend on the basal area, distribution and vigour of aspen in the parent stand, and the homogeneity of site conditions across the harvested area (Frey et al. 2003, Gradkowski et al. 2010). Relatively pure stands (i.e., $>80 \%$ of stand basal area to a single species) of spruce or pine may also be established on these sites through seeding or planting, followed by vegetation management when needed to reduce competition from aspen, tall shrubs, and herbaceous vegetation. However, maintenance of a desired complement of stands in a mixed species condition within the managed forest can be a challenge, particularly where the lengthy rotations needed for natural succession to create these stands are impractical and the resulting conifer component is unpredictable. As a result, there has been mounting concern for a tendency on the part of forest managers to "unmix the mixedwoods" (Stuart-Smith 1995).

Acknowledging the need to produce both aspen and conifer for commercial demand, while maintaining the ecological goods and services provided by mixedwoods, a number of research efforts have been directed towards creating spatial mixtures, through various arrangements of pure groupings of spruce and aspen (Groot et al. 1996, Groot 1999, Comeau et al. 2005, Man et al. 2013), or intimate mixtures (with species separation on the scale of a few metres or less) by using mature or semimature aspen as a shelterwood for the regeneration of a younger age class of spruce (Lieffers and Beck 1994, Lieffers et al. 1996, Comeau et al. 2004, 2009). These approaches serve various ecological objectives, but share potentially serious operational shortcomings in the spatial and structural complexity of the stands that they create. For example, harvesting spruce and aspen, each with very different optimum rotation ages, necessitates multiple interventions that can be cost prohibitive under complex spatial arrangements of the two species. In addition, relatively high densities of understory spruce make the removal of overstory aspen difficult or impossible to conduct without incurring damage to the spruce (DeLong 1991, Navratil 1996). Regenerating a single-cohort, intimate mixture that might alleviate these shortcomings remains a significant challenge in boreal silviculture (Kabzems et al. 2007).

Research and operational experience have shown that fairly rigorous vegetation management is required to counter the natural propensity of upland boreal sites to regenerate aspen following harvest (Wood and von Althen 1993, Cole et al. 2003, Pitt and Bell 2005, Boateng et al. 2006) and that unintentional, intimate mixedwoods are often the result of conventional conifer regeneration efforts (Navratil et al. 1991, Pitt et al. 2004a; 2004b, Pitt and Bell 2005). In 2000, we worked with a coalition of forest industry partners to formulate and test a practical regeneration strategy for a singlecohort, intimate mixture of spruce and aspen that would capitalize on the natural propensity of these sites to regenerate aspen following harvest. Our hypothesis was that white spruce may be planted at 5-m spacing (400 stems per ha $\mathrm{sph}$ ) and grown alongside naturally regenerating aspen, given vegetation management that provides approximately equal sharing of site resources. The goal would be to produce an early technical rotation of aspen $(\sim$ age 30$)$ and a long-term sawlog rotation of spruce (age 60 or older); given a spatial arrangement of the two species that facilitates early vegetation management treatment and aspen removal using conventional cut-to-length harvesting systems. In theory, the benefits derived from this strategy would include creation and maintenance of controlled mixes of spruce and aspen stands where desired; facilitative effects of the aspen on spruce, including promotion of nutrient cycling, good stem form and mitigation of climatic extremes, insects, and diseases; minimizing the number of trees planted and subsequently tended; reducing area involved in vegetation management treatment; conserving original tree and understory plant diversity on sites; and promoting social acceptance through a more integrated management approach.

In 2002, we initiated a field experiment that was replicated in the western and eastern Canadian boreal forest and designed to test our single-cohort, intimate mixture regeneration strategy, comparing it to alternative strategies ranging from pure aspen to pure spruce outcomes. The fifth growing season results of this experiment were reported by Pitt et al. (2010). Our objectives herein are to use tenth-year data from this study to re-evaluate the nature and duration of vegetation control necessary to optimize early mixedwood stand development under the hypothesized strategy. 


\section{Methods}

A detailed description of the study sites and experimental methods can be found in Pitt et al. (2010). A summary is provided herein for convenience.

\section{Study areas}

Mature stands scheduled for harvest were chosen near Whitecourt, Alberta (AB) (NAD83: 54 $22^{\prime} \mathrm{N}, 115^{\circ} 35^{\prime} \mathrm{W}$, elevation $1000 \mathrm{~m}$; licenced to Blue Ridge Lumber (1981) Ltd.) and Timmins, Ontario (ON) (NAD83: $48^{\circ} 18^{\prime} \mathrm{N}, 81^{\circ} 15^{\prime} \mathrm{W}$, elevation $340 \mathrm{~m}$; licenced to Tembec). The parent AB stand was of fireorigin, aged 75 years and dominated by trembling aspen, with small components of lodgepole pine and balsam poplar ( $P o p-$ ulus balsamifera L.) scattered throughout. Average basal area was $33 \mathrm{~m}^{2} /$ ha, distributed over approximately $550 \mathrm{sph}$, with a mean diameter at breast height $(\mathrm{DBH})$ of $26.5 \mathrm{~cm}$ and a stand height of $23.5 \mathrm{~m}$ (site index of 18.6 for aspen and 16.3 for lodgepole pine). Merchantable volume consisted of $26 \mathrm{~m}^{3} / \mathrm{ha}$ of conifer (70 sph, $4 \mathrm{~m}^{2} / \mathrm{ha}$ ) and $191 \mathrm{~m}^{3} /$ ha of deciduous (480 $\mathrm{sph}, 29 \mathrm{~m}^{2} / \mathrm{ha}$ ). Soils across the site were assessed as mesic, fine-textured Luvisols (Soil Classification Working Group 1998), with parent material consisting of a fluvial veneer overlying ablation till and a rounded cobble layer at about 25-40 $\mathrm{cm}$, resulting from glacio-fluvial action. Texture ranges between silty-loam over clay, to a sandy-loam veneer over silty clay-loam.

The parent $\mathrm{ON}$ stand consisted of a pure aspen overstory with a well-developed black and white spruce understory. Aspen were 82 years old and averaged $340 \mathrm{sph}, 20.4 \mathrm{~m}^{2} /$ ha basal area, $25 \mathrm{~m}$ height, $27 \mathrm{~cm} \mathrm{DBH}$, and site index 20. Spruce ranged in age from 61 to 82 years and averaged $370 \mathrm{sph}, 9.1$ $\mathrm{m}^{2} /$ ha basal area, 12-22 $\mathrm{m}$ height, and $17 \mathrm{~cm} \mathrm{DBH}$. Merchantable volume consisted of $66 \mathrm{~m}^{3} /$ ha of conifer and 150 $\mathrm{m}^{3} /$ ha of deciduous. Soil across the site was assessed as an Orthic Humo-Ferric Podzol (Soil Classification Working Group 1998) of glacio-fluvial origin. Loamy to coarse sand parent materials are overlain by $50 \mathrm{~cm}$ of silt to very fine sandtextured materials, providing a well-drained, fresh site. The $\mathrm{AB}$ and $\mathrm{ON}$ sites were full-tree logged in March of 2002 and 2003, respectively. In May following harvest, potential plot areas were homogenized and prepared for the experiment by removing coarse woody debris (over $10 \mathrm{~cm}$ in diameter) and cutting all residual brush. Plots were then installed and spruce planting positions pinned, consistent with the study design and randomization.

\section{Experimental design}

The study design consists of a total of eight treatments, each applied to at least three replicate plots at each site (Fig. 1). Three treatments were chosen to address the hypothesized mixedwood regeneration strategy and consist of 2-m "radial" vegetation control treatments applied to white spruce planted at 5-m spacing in $45-\mathrm{m} \times 45-\mathrm{m}$ plots (Fig. 1a). These treatments include annual removal of woody vegetation (herein meaning all deciduous tree and tall shrub species capable of reaching at least 2-m in height) (RW); annual removal of woody vegetation, combined with control of herbaceous vegetation (herein including grasses, forbs, ferns, and low-shrub (less than 2-m height potential) growth forms) for the first two growing seasons ( $\mathbf{R C}_{2}$ ); and annual removal of woody vegetation, combined with control of herbaceous vegetation for the first four growing seasons $\left(\mathbf{R C}_{\mathbf{4}}\right)$. All treatments involving "annual removal" were maintained for the first ten growing seasons of the experiment.

Additionally, five "broadcast" treatments were chosen to contrast the radial mixedwood treatments in 35- $\mathrm{m} \times 35-\mathrm{m}$ plots (Fig. 1b). The first treatment is an unplanted and untended control, with the intention of aspen-dominant regeneration (BA). The remaining four treatments were applied to spruce planted at 2.5-m spacing: annual removal of woody vegetation (BW); annual removal of herbaceous vegetation (BH); annual removal of both woody and herbaceous vegetation (BC); and no vegetation control (BN).

Each installation of the experiment consists of a total of 40 treatment plots. Within each site, treatment assignments were completely random. The number of replicates of each treatment, outlined in Fig. 1, were chosen to accommodate a future thinning of the aspen in the radial treatment plots, giving rise to a response-surface design consisting of duration of herbaceous vegetation control $X$ aspen stem density. These thinnings were implemented at the $\mathrm{AB}$ site immediately after the $10^{\text {th }}$-year data collection and are therefore not a part of the analyses reported herein. Aspen stem densities at the $\mathrm{ON}$ site were deemed to be too low to warrant thinning.

Given the propensity of the two sites to naturally regenerate aspen, the treatments may be grouped as five potential "mixedwood" outcomes ( $\mathbf{B N}, \mathbf{B H}, \mathbf{R W}, \mathbf{R C}_{2}$, and $\mathbf{R C}_{4}$ ), two spruce-dominated outcomes (BW and BC) and one aspendominated outcome (BA). The latter effectively represents minimal silvicultural expenditure and intervention. The planted, untended condition (BN) reflects a mixedwood goal, but with no silvicultural expenditure beyond planting. Herbaceous-only control (BH) reflects a mixedwood goal potentially achieved through understory competition control, without the aspen canopy openings created by the radial treatments. The radial mixedwood treatments $\left(\mathbf{R W}, \mathbf{R C}_{2}\right.$, and $\mathbf{R C}_{4}$ ) each reflect progressively increasing vegetation management intensities. In contrast, the spruce-only treatment (BC) is intended to reflect the maximum growth potential of white spruce alone, under fairly intensive tending. Woody-vegetation-only control (BW) reflects a spruce production goal, but without the intensity of vegetation management needed to achieve herbaceous competition control.

Treatment applications were initiated at each site near the end of the first growing season following harvest (the year prior to planting). Radial treatment plots receiving woodyonly control (RW) were treated using a backpack basal bark application (streamline method) with triclopyr butoxyethyl ester (Release ${ }^{\circledast}$ ) and mineral oil mixed 25:75 by volume. These treatments targeted all tall-shrub and deciduous tree vegetation within a $2-\mathrm{m}$ radius around each spruce planting location (Fig. 1a). On broadcast treatment plots receiving woody-vegetation-only control (BW), all such stems situated within the plot boundaries were treated using this same method (Fig. 1b).

Radial treatment plots receiving two or four years of herbaceous vegetation control $\left(\mathbf{R C}_{2}\right.$ and $\mathbf{R C}_{\mathbf{4}}$ ) were site prepared using glyphosate $\left(\right.$ Vision $^{\circledR}$ ) and $0.375 \%$ SylGard $^{\circledR}$ 309, applied within a 2-m radius around each spruce planting location. A backpack-equipped, hand-held rotating boom was used to apply $9 \mathrm{~L} / \mathrm{ha}$ (3204 g ae glyphosate/ha) in 100 $\mathrm{L} /$ ha of solution in $\mathrm{AB}$; a directed foliar application (3\% solution) with an 8004 nozzle was used in ON. On broadcast treatment plots receiving complete, whole-plot vegetation 


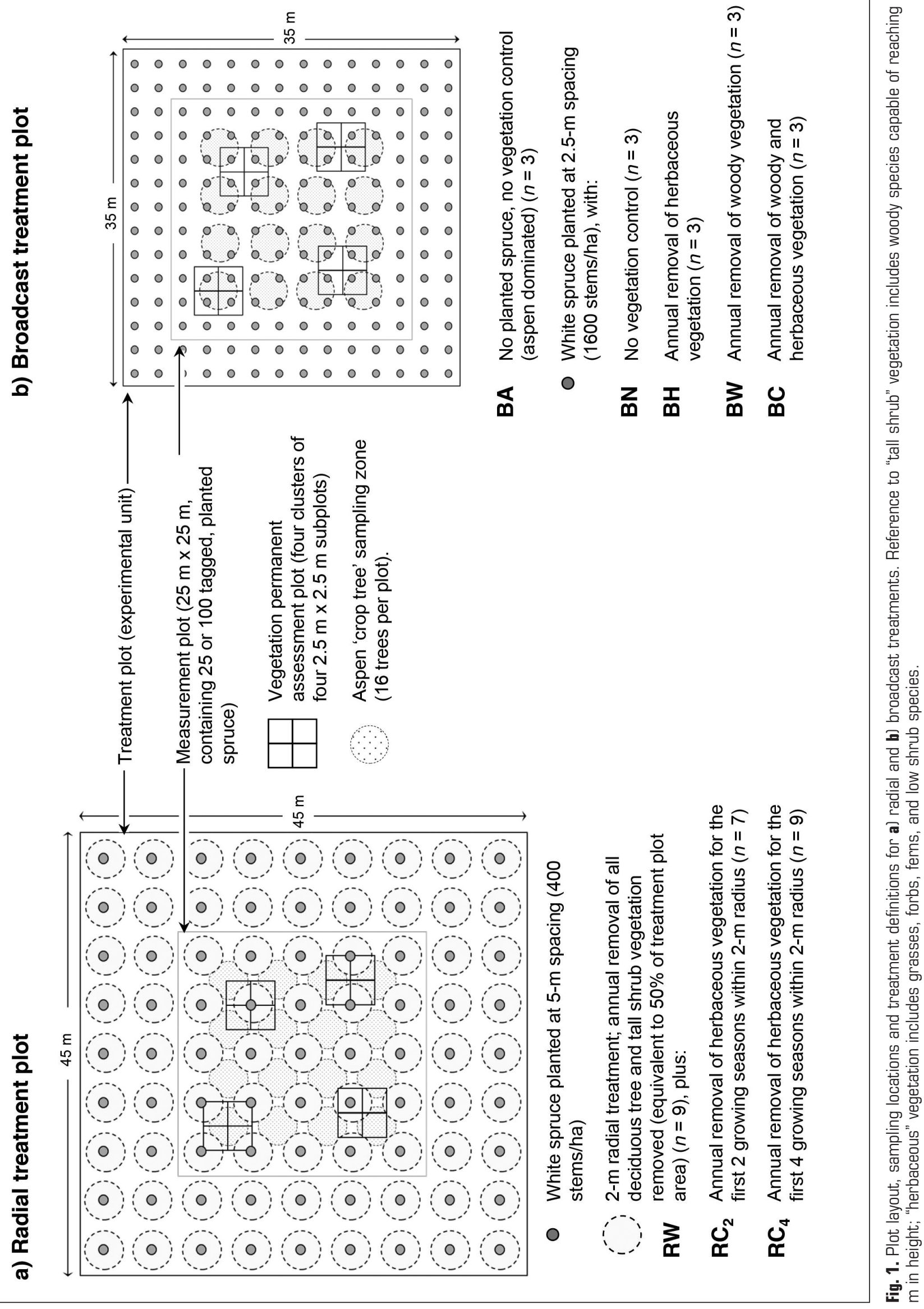


control (BC), the same mixtures/rates were applied with a 2$\mathrm{m}$ spray boom equipped with 11002 Turbo TeeJet nozzles in $\mathrm{AB}$, or in a directed-foliar application in Ontario. On the three $\mathrm{AB}$ plots receiving whole-plot herbaceous-only vegetation control (BH), a backpack equipped, roller-wipe applicator was used to treat all vegetation within the plot boundary, except aspen. This approach enabled us to treat Calamagrostis canadensis (Michx.) Beauv. (Canada blue-joint grass) without affecting aspen when these two species were coincident. The same plots in ON were successfully treated using carefully directed foliar applications of glyphosate ( $2 \%$ solution).

The $\mathrm{AB}$ and $\mathrm{ON}$ sites were planted during the spring of 2003 and 2004, respectively, using container stock $2+0$ white spruce. Post-planting vegetation control treatments were maintained as dictated by the experimental design. Woody vegetation was controlled via manual clipping. Herbaceous vegetation was controlled through one or more mid-growing season manual weedings, followed by a carefully directed foliar application of glyphosate ( $2 \%$ solution) at the end of the growing season.

\section{Vegetation assessments}

Vegetation assessments were conducted within the centre 25$\mathrm{m} \times 25$ - $\mathrm{m}$ portion of each treatment plot. Each such measurement plot contains 25 (Fig. 1a) or 100 (Fig. 1b) numbered and tagged planted spruce, depending on the assigned treatment. Consistent with the measurements made at the time of planting (year 0) and end of each subsequent growing season through to year 5 and year 7 , these trees were measured at the end of the $10^{\text {th }}$ growing season for total height (HT; nearest $\mathrm{cm}$ ), crown diameter (maximum and $90^{\circ}$ to maximum, nearest $\mathrm{cm})$, and stem diameter $\left(\mathrm{D}_{5} ; 5-\mathrm{cm}\right.$ above ground line, nearest $\mathrm{mm}$ ). Trees were also visually rated for health using a 5-class system (HC: 1 = vigorous, 2 = healthy, $3=$ mediocre, 4 $=$ moribund, and $5=$ dead) (Pitt et al. 1992). Equivalent measures were also made on 16 aspen "crop trees" evenly distributed throughout each measurement plot. These trees were selected as the best stems present at the time of measurement within sixteen $2.5-\mathrm{m}$ radius stocking quadrats centred between the spruce planting locations in the measurement plot (Fig. 1), based on a combination of superior health, form and height, in this order of priority.

Consistent with the non-crop vegetation assessments conducted the year of planting (year 0 ) and mid-July of each subsequent growing season through to year-5, $10^{\text {th }}$-year data were collected from 16 systematically located $2.5-\mathrm{m} \times 2.5-\mathrm{m}$ subplots within each measurement plot (4 clusters of 4 subplots; Fig. 1). Separate evaluations were made for planted spruce, other conifers, aspen, other deciduous trees, tall shrubs, low shrubs, ferns, forbs, Calamagrostis, and other grass/sedge life forms. Cover (\%) was visually estimated as the portion of the subplot ground surface occupied by the vertical projection of the plant foliage to the nearest $5 \%$. Trace amounts of cover were assigned a value of $1 \%$. Species composition (five most dominant species) and proportional abundance were noted for the other conifer, other deciduous tree, tall shrub, low shrub, fern, and herbaceous categories. All aspen and other deciduous tree stems situated on these plots were counted and a typical codominant stem measured for total height and basal stem diameter $(15-\mathrm{cm}$ above ground level) for each species.

\section{Statistical analyses}

Tenth growing season measurements were used directly or in combination to describe the vertical and horizontal vegetation responses to the treatments (Fig. 2). Mean cover and height values were calculated for each life form and averaged across replicate plots within treatments to describe and illustrate patterns of vegetation abundance and dominance. Being largely descriptive information, these values were not subjected to any further statistical analyses.

For spruce and aspen crop trees, composite measures included crop-tree crown diameter (CD), calculated as the geometric mean of the two measures taken, and stem volume index $\left(\mathrm{SVI} ; \mathrm{cm}^{3}\right)$, calculated from stem height and diameter, assuming conical form. Additionally, crop-tree height growth rates at age 10 were obtained by fitting a second-order polynomial to the 10 years of growth data for each treatment plot, and then evaluating the first derivative of the resulting function at age 10:

[1] $\mathrm{HT}=\mathrm{b}_{0}+\mathrm{b}_{1}$ Year $+\mathrm{b}_{2}$ Year $^{2}$,

[2] $\mathrm{HT}^{\prime}=\mathrm{b}_{1}+2 \times \mathrm{b}_{2} \times$ Year, and

[3] $\operatorname{HT}^{\prime}(10)=b_{1}+2 \times b_{2} \times 10$,

where $b_{0}, b_{1}$ and $b_{2}$ are parameter estimates from least squares regression, Year is the number of years after plantation establishment and $\mathrm{HT}^{\prime}$ is the first derivative or growth rate. Frequencies of dead $(\mathrm{HC}=5)$ and healthy $(\mathrm{HC} \leq 2)$ planted spruce were expressed as percentages for each treatment plot. Treatment-plot means for the crop tree response variables were then subjected to analyses of variance (ANOVA) by study site using a model appropriate for a completely randomized design. Treatment $\times$ Site interactions prevented our combining sites in these analyses. Model residuals were examined to verify compliance with homogeneity of variance and normality assumptions, and treatment means were compared using Tukey's studentized range test $(\alpha=$ $0.05)$. All statistical analyses were conducted with SAS ${ }^{\circledast}$ statistical software (SAS Institute Inc., Cary, NC).

\section{Results}

\section{Vegetation patterns}

Ten growing seasons after initiation of the experiment, the treatments were generally producing their intended broad target outcomes (Fig. 3 and Fig. 4): aspen (BA); mixedwood (BN, $\mathbf{B H}, \mathbf{R W}, \mathbf{R C}_{2}$, and $\mathbf{R C}_{4}$ ); and spruce (BW and $\mathbf{B C}$ ). In treatments retaining woody vegetation, aspen was height-dominant over all other life forms, reaching averages of five metres in $\mathrm{AB}$ and more than six metres in ON. In its undisturbed state (BA, BN, BH), aspen cover averaged between $54 \%$ and $61 \%$, with stem densities just over $30000 \mathrm{sph}$ in $\mathrm{AB}$ and $11000 \mathrm{sph}$ in ON. These densities were down from the 59000 and 20000 sph observed at year 5 on these sites, respectively, indicating that self-thinning was still taking place in these stands through year 10. As expected, the radial treatments $\left(\mathbf{R W}, \mathbf{R C}_{2}, \mathbf{R C}_{\mathbf{4}}\right)$ contained approximately half the cover and density of aspen observed in the undisturbed plots. Other deciduous tree species, largely white birch (Betula papyrifera Marsh.) and balsam poplar were minor components of the stands at both sites, occupying no more than $7 \%$ cover. 


\section{Stand height $(\mathrm{m})$}

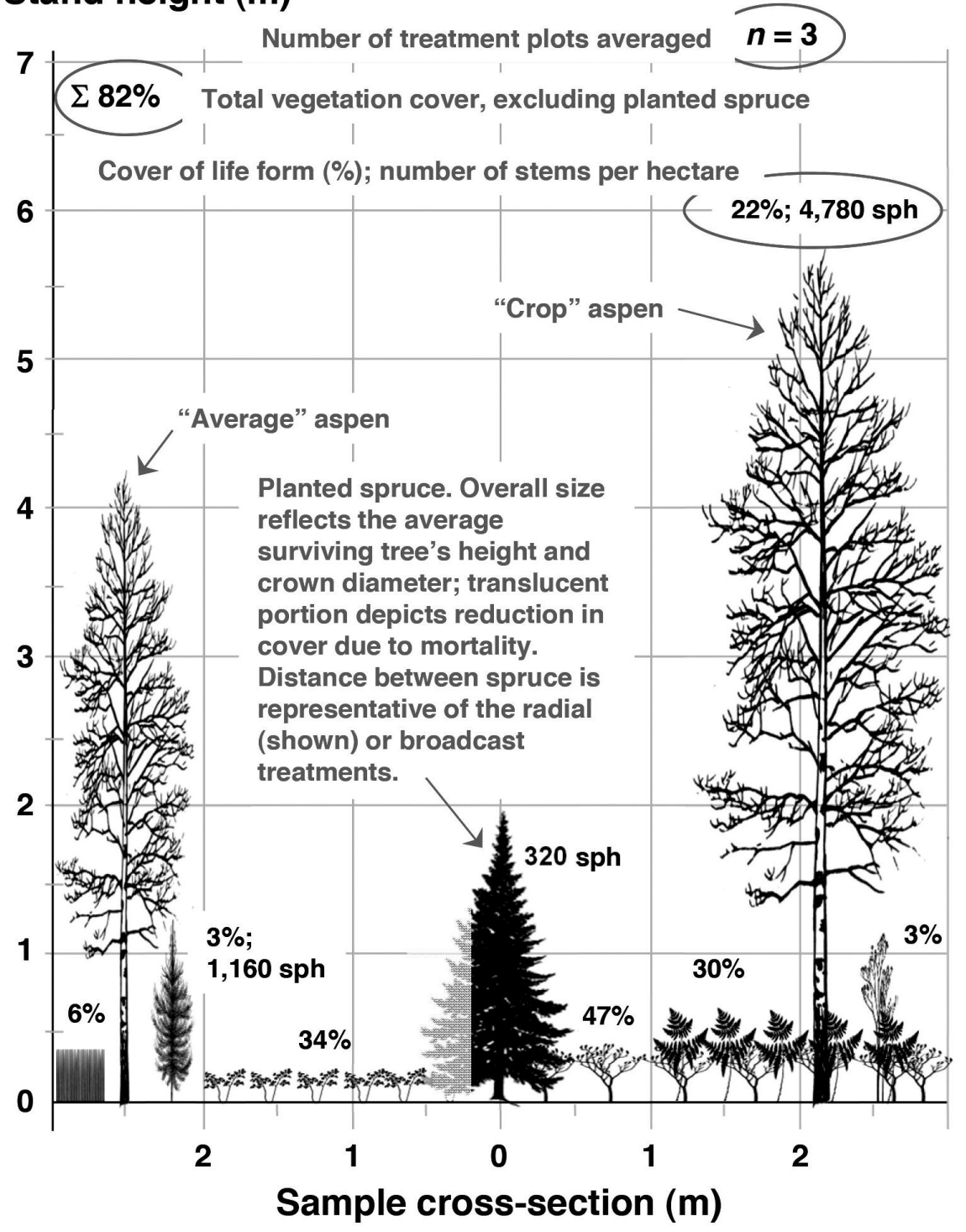

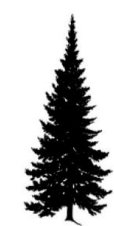

Planted white spruce

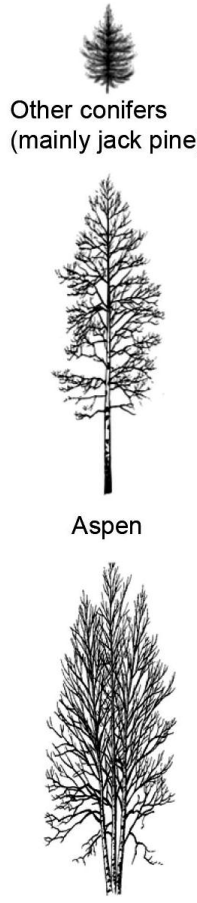

Other tree species (mainly white birch)

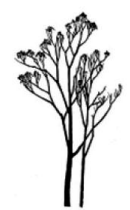

Tall shrub species

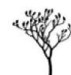

Low shrub species

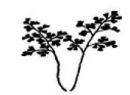

Forb species
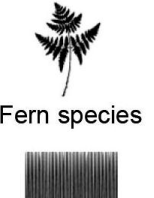

Grass species

Fig. 2. Key to the interpretation of vegetation schematics shown in Fig.3 and Fig. 4. Each diagram depicts the "average" vegetation condition observed on $n$ replicate treatment plots. Planted spruce are drawn to scale based on height and crown diameter measured from the tagged trees in each measurement plot (Fig. 1). "Crop" aspen are drawn to scale based on height and crown diameter measured from the 16 trees with best growth and form distributed across each plot (Fig. 1). All other life forms are drawn to reflect their height and cover, based on a 6-m sample cross-section, and averaged from assessments made on sixteen 2.5-m $\times 2.5-\mathrm{m}$ sample quadrats in each plot. 

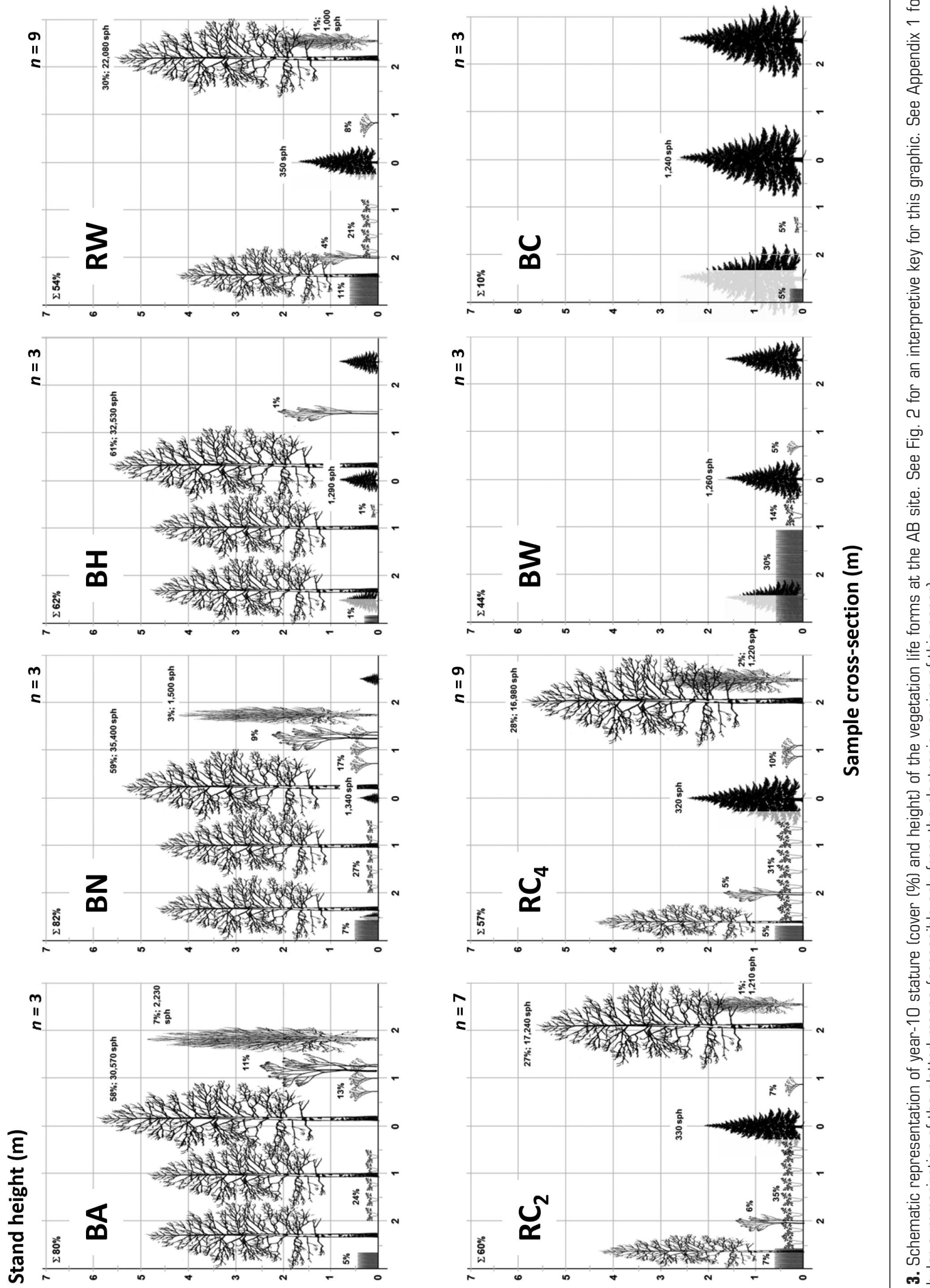

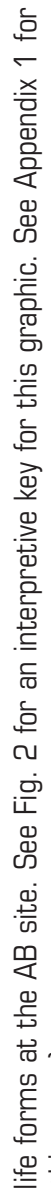

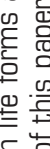

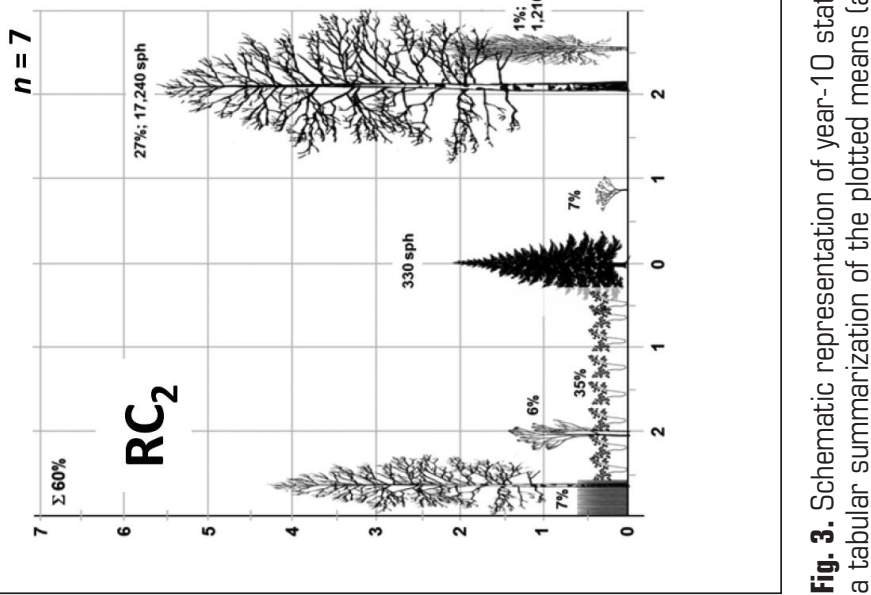



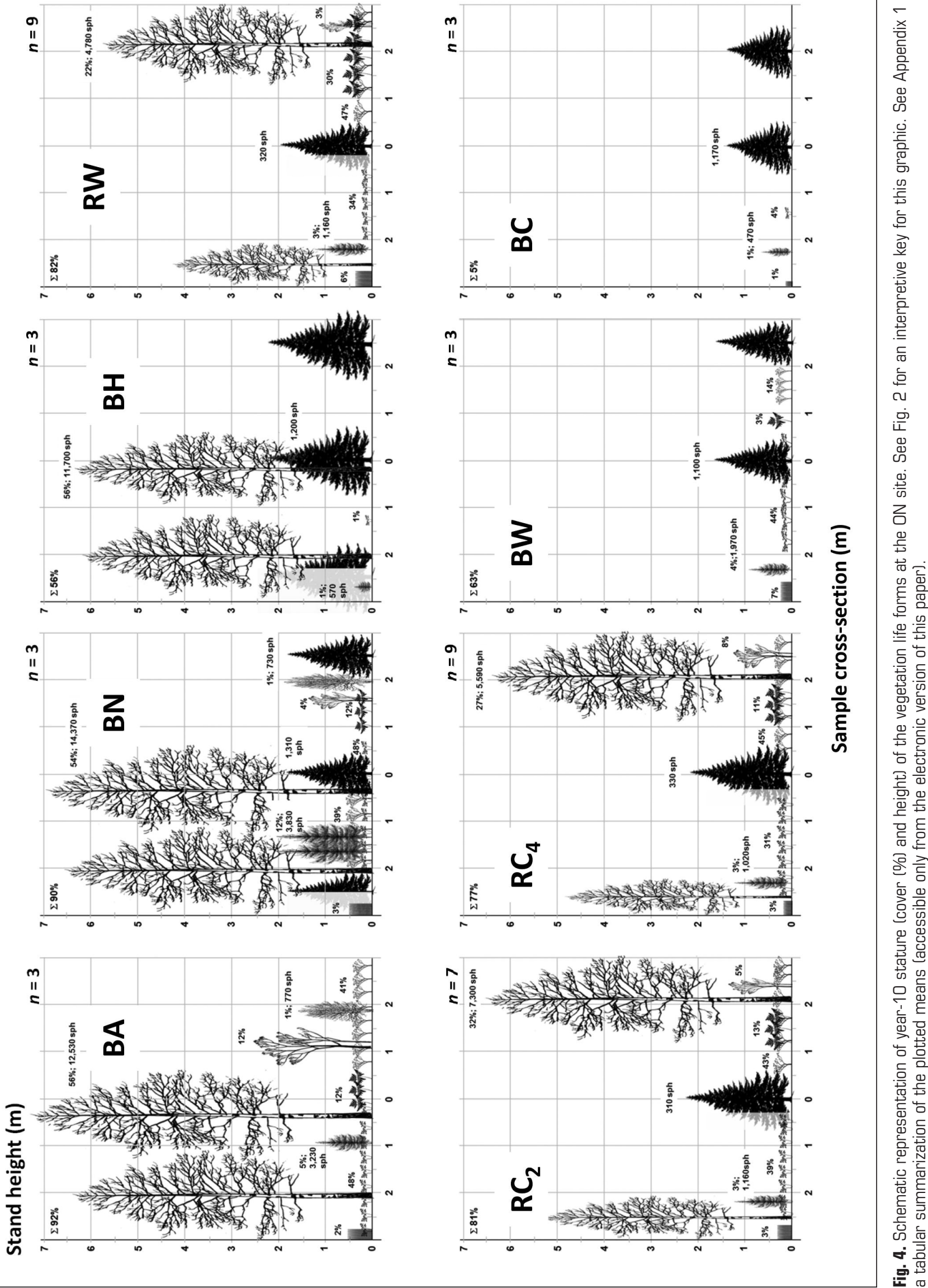
Conifers, other than planted spruce, were not very common across either site. In $A B$, white spruce and, to a lesser extent balsam fir and lodgepole pine, were observed infrequently across all plots except those left in an undisturbed state (BA and $\mathbf{B N})$. Cover and stem densities were less than $1 \%$ and 240 sph, respectively. In ON, jack pine, black spruce, white spruce, and balsam fir were observed with cover and density values ranging from less than $1 \%$ (470 sph) in BC plots to $12 \%$ (3830 sph) in BN plots. As of year 10, the natural ingress of conifers was not considered to be competing with the planted spruce in any of the plots.

Tall shrub species were present as minor components in all treatment plots except $\mathbf{B W}$ and $\mathbf{B C}$. Year 10 cover ranged between $4 \%$ and $12 \%$ on fully undisturbed plots (BA and $\mathbf{B N}$ ) and $1 \%$ or less in $\mathbf{B H}$ plots, suggesting that some of these plants were collaterally included in herbaceous weed control efforts in these plots. Species included Alnus crispa and Salix spp. (descending order of cover-weighted dominance) in AB and Prunus pensylvanica, Acer spicatum, Salix spp., Corylus cornuta, Sorbus americana and Amelanchier spp. in ON.

Low shrub species were moderately prominent across all plots except those receiving complete vegetation control (BC) or herbaceous-only control $(\mathbf{B H})$. In $\mathrm{AB}$, year 10 covers ranged from $13 \%$ to $17 \%$ in undisturbed plots (BA, BN), and between $7 \%$ and $10 \%$ in radial treatment plots. Viburnum edule was the most commonly encountered species, with Rubus idaeus, Rosa acicularis, Lonicera involucrata and Ribes triste being common secondary species. Low shrubs attained higher cover values in $\mathrm{ON}$ than observed in $\mathrm{AB}$, ranging from $39 \%$ to $41 \%$ in undisturbed plots, to $43 \%$ to $47 \%$ in radially treated plots. Rubus idaeus and Diervilla lonicera were commonly encountered, with Ribes glandulosum and Vaccinium spp. being common subordinate species.

In undisturbed plots (BA, BN), year 10 forb cover was dominated by Aralia nudicaulis in AB, averaging 24\% to $27 \%$ cover, and Aralia nudicaulis and Cornus canadensis in ON, averaging nearly 50\% cover. Dominance by Aralia nudicaulis and Cornus canadensis continued across ON's radially treated plots, although covers dropped slightly to between $31 \%$ and $39 \%$. These same plots in AB tended to be dominated by Epilobium angustifolium, averaging $21 \%$ to $35 \%$ total forb cover. In BW plots, Epilobium angustifolium dominated forb cover in $\mathrm{AB}$, averaging $14 \%$, compared to dominance by Hieracium spp. and higher covers (44\%) in these same plots in ON.

Ferns were generally more common in year 10 on the $\mathrm{ON}$ site than in $\mathrm{AB}$, with Pteridium aquilinum being observed across all plots except $\mathbf{B C}$ and $\mathbf{B H}$. Dryopteris carthusiana was commonly observed in ON's BA and $\mathbf{B N}$ plots as well as the undisturbed portions of the radially treated plots. On these same plots, Athyrium filix-femina ssp. angustum and Osmunda claytoniana were also found. Total fern cover in ON ranged from $12 \%$ to $30 \%$ across $\mathbf{B A}, \mathbf{B N}$, and the radially treated plots. In contrast, ferns, primarily Gynmocorpium dryopteris, were only observed in trace amounts across the $A B$ site.

Grasses, dominated by Calamagrostis, were more common in year 10 at the $\mathrm{AB}$ site than the $\mathrm{ON}$ site. Consistent with the $5^{\text {th }}$-year observations, woody-only vegetation control was associated with the highest grass covers in $\mathrm{AB}$, at $11 \%$ cover in RW plots and more than double this amount in BW plots. Undisturbed $\mathrm{AB}$ plots retained $5 \%$ to $7 \%$ grass cover in year 10. In contrast, grass and sedge species were not as prominent across the ON site, with covers ranging between $1 \%$ and $7 \%$. Consistent with $\mathrm{AB}$, the woody-only vegetation control plots contained the highest grass/sedge covers at $6 \%$ to $7 \%$.

Aggregating cover from all of the non-spruce life forms, total non-spruce vegetation cover tended to be slightly higher in $\mathrm{ON}$ plots than in equivalent $\mathrm{AB}$ plots. For example, total cover on undisturbed plots in ON averaged $90 \%$ to $92 \%$, compared to $80 \%$ to $82 \%$ in $\mathrm{AB}$. Similarly, radial plots in $\mathrm{ON}$ tended to have higher cover values, averaging $77 \%$ to $82 \%$, compared to just $54 \%$ to $60 \%$ in $\mathrm{AB}$, largely due to the higher fern and low-shrub values occurring at the $\mathrm{ON}$ site. Where only the herbaceous vegetation was removed $(\mathbf{B H})$, however, cover values in $\mathrm{AB}(62 \%)$ were slightly higher than $\mathrm{ON}$ (56\%), largely due to small differences in aspen cover. Collectively, these cover values have not changed substantively since the year 5 assessments (Pitt et al. 2010).

\section{Crop tree response \\ Planted spruce}

Mortality of planted spruce continued to steadily increase across both sites, up from $12 \%$ at year 5 in $\mathrm{AB}$ to $18 \%$ in year 10 , and from $11 \%$ to $21 \%$ over the same period in ON (Table 1). Although the treatments had no statistical associations with mortality $(p \geq 0.65)$, trees in undisturbed plots $(\mathbf{B N})$ were consistently among those with the lowest mortality rates and those in $\mathbf{B W}$ and $\mathbf{B C}$ the highest, as observed in earlier years. At the ON site, similar trends were observed with the percentage of trees classed as "healthy" (health codes 1 and 2): BN had the highest proportion of healthy trees (78\%), and BW and BC the lowest $(\leq 48 \%)(p<0.05)$, although the other mixedwood treatments also supported reasonable proportions of healthy trees $(72 \%-76 \%)$. Two major frost events occurring June 6, 2007 (year 4) and May 7-11, 2010 (http://climate.weather.gc.ca/) can be linked to these trends in both health and mortality observed at the ON site, with the very exposed trees on these spruce-only plots bearing the brunt of the damage. In $\mathrm{AB}$, all of the treatments except those with fully intact aspen (BN, BH) had similar proportions of healthy trees $(\geq 71 \%)$. In plots with the heaviest aspen cover and shorter spruce, we observed substantial rabbit browsing which dramatically affected the health $(p<0.05)$ and size of these planted spruce (Fig. 3).

The treatments generally had a strong influence on planted spruce growth $(p<0.05)$ across both sites (Fig. 3 and Fig. 4; Table 1). Total height, which is often invariant to the effects of competition (Lanner 1985) was similar across AB complete control (BC) and radial treatments, ranging from $175 \mathrm{~cm}$ to $260 \mathrm{~cm}(p \geq 0.05)$. Of the spruce-only treatments, BW supported the shortest spruce $(164 \mathrm{~cm})$, a full metre less than the same trees growing without herbaceous competition (BC). Extensive browsing in $\mathbf{B N}$ and $\mathbf{B H}$ plots kept trees well below $90 \mathrm{~cm}$ total height and largely unable to grow out of reach of the rabbits causing the damage. Year 10 height growth rates in $\mathrm{AB}$ were greatest ( $\geq 36 \mathrm{~cm} /$ year) for trees receiving herbaceous weed control $\left(\mathbf{R C}_{2}, \mathbf{R C}_{4}\right.$, and $\left.\mathbf{B C}\right)$, moderate $(30 \mathrm{~cm})$ for those receiving woody control (RW and $\mathrm{BW}$ ), and negligible ( $4 \mathrm{~cm} /$ year to $6 \mathrm{~cm} /$ year) in the plots with severe browsing (BN, BH). At the $\mathrm{ON}$ site, the tallest and fastest growing spruce tended to be found in the mixedwood plots, with plot averages ranging from $185 \mathrm{~cm}$ to $232 \mathrm{~cm}$, and $10^{\text {th }}$-year growth rates between $29 \mathrm{~cm} /$ year and $40 \mathrm{~cm} /$ year. The shortest and slowest growing trees were found in $\mathbf{B C}$ 


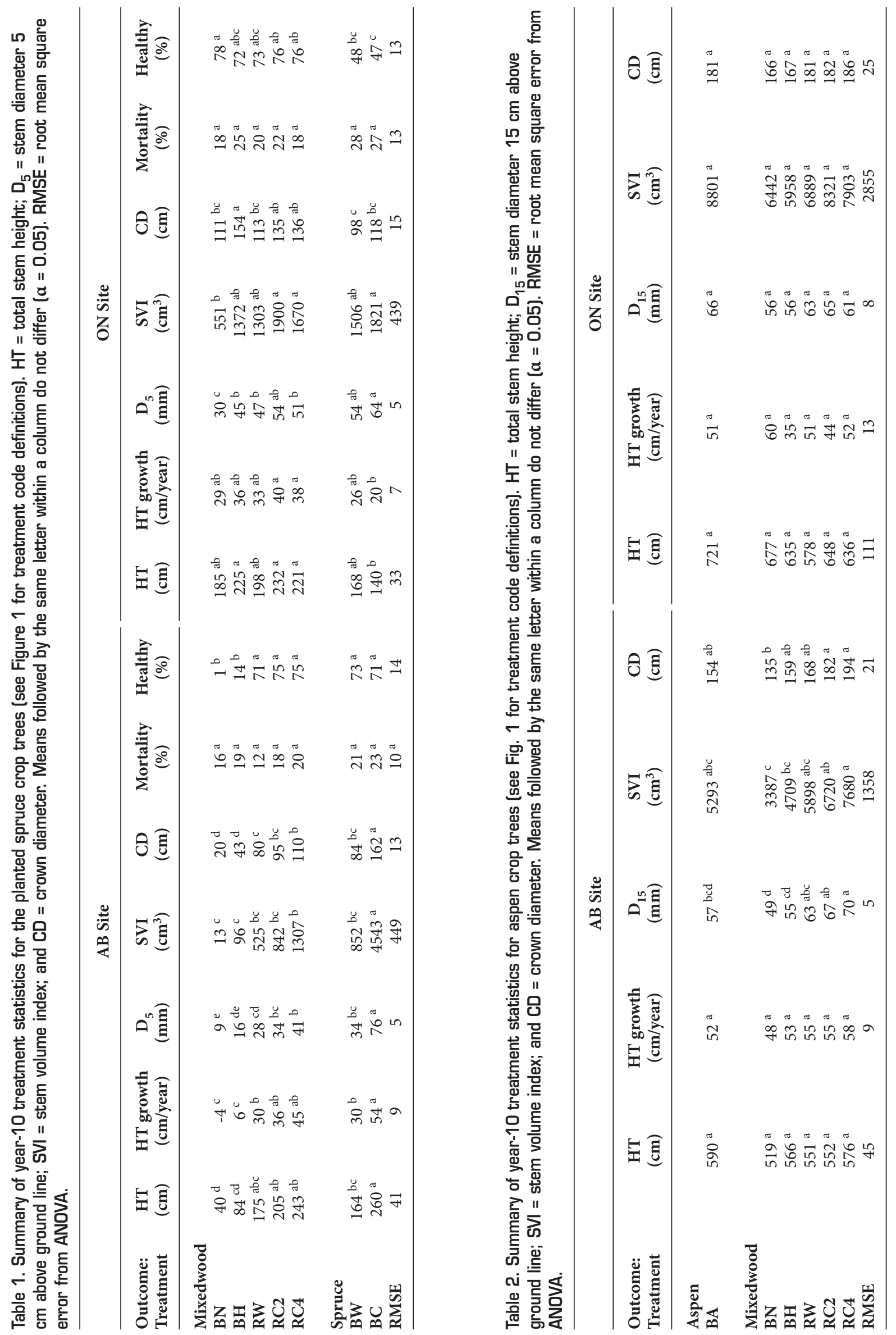


plots at $140 \mathrm{~cm}$ and $20 \mathrm{~cm} / y e a r$, a likely reflection of the severe frost damage observed there. In ON mixedwood plots, without the interference of rabbit browsing observed in $A B$, herbaceous weed control increased spruce height growth by more than $22 \%$ and height growth rates by more than $14 \%$. Similar gains were observed in response to herbaceous weed control in the $\mathrm{AB}$ radial plots $\left(\mathbf{R C}_{4}\right.$ and $\mathbf{R C}_{2}$ vs. $\left.\mathbf{R W}\right)$.

Stem diameter is known to be highly reflective of competition for growing resources (MacDonald et al. 1990, Wagner and Radosevich 1991, Man et al. 2008) and the treatments tested resulted in strong diameter responses that were fairly consistent across both sites (Table 1). Spruce growing without competition (BC) had the largest stem diameters observed in the study $(\geq 64 \mathrm{~mm})$. Spruce in radially treated plots with herbaceous weed control $\left(\mathbf{R C}_{2}\right.$ and $\left.\mathbf{R C}_{4}\right)$ and those receiving broadcast woody control (BW) had the next largest diameters, followed by trees in $\mathbf{R W}, \mathbf{B H}$, and $\mathbf{B N}$ plots, in that order. In a mixedwood context, herbaceous weed control increased spruce stem diameter growth by more than $12 \%$ in the radial treatments and $50 \%$ in broadcast treatments. Crown diameter should be closely correlated with stem diameter and the spruce in $\mathrm{AB}$ illustrate this fairly well. In $\mathrm{ON}$, however, the largest spruce crown diameters were found on mixedwood plots receiving herbaceous weed control $\left(\mathbf{B H}, \mathbf{R C}_{2}\right.$ and $\left.\mathbf{R C}_{4}\right)$. It is likely that the heavy frost damage incurred by the opengrown spruce (BC) contributed to the relatively small crown diameters observed in these plots.

Integrating stem diameter and height as stem volume index (SVI) reinforced observations that the effects of herbaceous weed control are strong and positive, and that the radial mixedwood treatments can produce reasonable early spruce growth (Table 1). At the AB site, herbaceous weed control had produced at least a two-fold increase in planted spruce SVI at year 10. At the ON site, such gains were in the order of $21 \%$ to $60 \%$. Regeneration to a mixedwood condition in which spruce and aspen share the site equally produced spruce with at least 30\% more SVI than if planted with undisturbed aspen and herbaceous weed control, and more than 2.3 times the SVI of spruce planted without any treatment at all.

\section{Aspen crop trees}

The height and height growth rates of select aspen at year 10 were treatment invariant ( $p \geq 0.05$; Table 2; Fig. 3 and Fig. 4 ). In $A B$, these trees averaged $560 \mathrm{~cm}$ tall and were growing at a rate of $55 \mathrm{~cm} /$ year; in $\mathrm{ON}$ they averaged $634 \mathrm{~cm}$ and were growing $49 \mathrm{~cm} /$ year. Trees in $\mathrm{AB}$ showed some positive stem diameter responses to radial treatments that had herbaceous weed control, with trees in $\mathbf{R C}_{2}$ and $\mathbf{R C}_{4}$ plots having stem diameters that were nearly $30 \%$ larger than those in undisturbed plots (BA, BN). These differences translated to stem volume gains of $66 \%$ and crown diameter gains of $30 \%$. Trees in the same plots at the ON site showed similar trends, but differences were not statistically significant $(p \geq 0.05)$.

\section{Discussion}

\section{Crop-tree growth trends relative to year-5}

In general, the growth trends established by year 5 for planted spruce and select aspen (Pitt et al. 2010) were maintained through year 10, with a few notable exceptions. At the AB site, spruce growth in competition-free plots (BC) increased exponentially. Despite one early season of winter freezing injury during low snow periods (Man et al. 2008), a subse- quent absence of damage from late spring frosts, insects, drought or other environmental factors has allowed these trees to capture the full growing potential of the site to benchmark near maximum growth for white spruce (our goal for testing this treatment). In contrast, severe frost damage and cumulative losses to root rot have resulted in the trees of the same treatment in ON underperforming in relative comparison. Second, the rate of diameter growth and health status of $\mathrm{AB}$ trees situated in broadcast woody-control plots (BW) have increased since year 5 , as these trees have grown above what was fairly serious Calamagrostis competition in earlier years (e.g., nearly $70 \%$ cover in year 4; now $30 \%$ in year 10 ). Finally, rates of diameter growth of aspen in $\mathrm{AB}$ radial plots has recently increased, suggesting a response of these aspen to the $50 \%$ thinning invoked by the radial treatments themselves and the ongoing self-thinning of the remaining aspen stems. While aspen in ON's radial plots are growing well, the same thinning effect was not observed, perhaps because of the substantially lower densities of aspen on these plots ( $\geq 16980 \mathrm{sph}$ in $\mathrm{AB}$ vs. $\leq 7300$ sph in ON; Fig. 3 and Fig. 4).

\section{Implications of within- and between-site variability}

The research plots in this study were large enough to capture and reflect a wide range of microsite variability typical of upland sites in the boreal forest. Localized growth and survival of regenerating spruce and aspen can be seriously impaired by relatively small topographic features that encourage frost formation, seasonal water retention and extreme drought. In a mature, natural stand, such features often go unnoticed because the existing stand is the net result of survival and growth in and around these features. However, these features will invariably affect the outcomes of silviculture that is applied in a broadcast fashion to these sites, especially croptree stocking. For example, where aspen were left to regenerate naturally on our study sites, year 10 cover reached a maximum of only $61 \%$, despite fairly high stem densities (> 11000 sph; $n=18$ plots) resulting from harvest timing and method being chosen to minimize site disturbance and favour aspen suckering (Frey et al. 2003). Small pockets of imperfect drainage and other locations where aspen simply did not regenerate (reasons unknown) can be blamed for this reduced stocking. Likewise, where spruce were planted, localized imperfect drainage, coupled with associated root infections, late spring frosts and winter injury gradually resulted in an average mortality rate of $20 \%$ by year 10 across our two study sites, rates that in our experience are not uncommon in operational plantings in the boreal. While some of these factors have discouraged managers from establishing white spruce plantations in the past (Sutton and Weldon 1996), they serve to underscore the use of silvicultural tools that offer the flexibility of being targeted towards suitable microsites.

Although this experiment was replicated on just two boreal sites, it is clear from this small sample that, along with microsite variation, many between-site factors exist to dissuade the wise forest manager from excessive use of any one silvicultural tool. For example, despite being situated on an equally productive site, $\mathrm{AB}$ aspen were still smaller, on average, than $\mathrm{ON}$ aspen at year 10 . This is very likely a carry-over effect of a severe hail storm that these trees endured July 9 , 2005 (year 3), which caused extensive defoliation and stem scarring. Moose browsing, severe drought, diseases such as Shepherd's crook (Venturia macularis) and insect pests such 
as large aspen tortrix (Christoneura conflictana) and Bruce spanworm (Operophtera bruceata), also pose very real risks for any forest manager relying solely on aspen as a crop (Burns and Honkala 1990, Perala 1990). Also unpredictable is the intensity with which aspen regenerates due to a variety of factors (Bates et al. 1989, Frey et al. 2003), as evidenced by the widely different regeneration densities at our two sites, despite similar parent stands and treatment. Likewise, planted spruce are susceptible to many seemingly random hazards including insects, seasonal drought, late spring frosts, diseases and insects, suggesting that an overreliance on the regeneration of this species would also involve considerable risk, particularly given relatively high establishment costs (Nienstadt and Zasada 1990). The influence of frost and some of the microsite factors mentioned above functioned to reduce the performance of our pure spruce treatments (BW and $\mathbf{B C}$ ) in $\mathrm{ON}$ relative to $\mathrm{AB}$, despite one season of winter freezing injury during low snow periods in $\mathrm{AB}$ (Man et al. 2008). The rabbit browsing (Radvanyi 1987) that occurred in the $\mathrm{AB}, \mathbf{B N}$, and $\mathbf{B H}$ plots may be reflective of operational settings where rabbit densities are high and predator densities happen to be low; however, this balance was likely facilitated in our study by the "elk fence" surrounding the $\mathrm{AB}$ plots (intended to discourage opportunistic oil and gas development). Clearly, employing a mix of regeneration strategies within the context of an integrated vegetation management program (Wagner 1993) is the most appropriate means of creating a diverse range of outcomes with potential to buffer against losses from insects, weather, disease, competition and a host of other factors.

\section{Vegetation management for mixedwood regeneration}

This study was established to generate better understanding of vegetation interactions on upland, mesic boreal sites so that consistent, effective and scientifically based vegetation management prescriptions might be designed for the regeneration of single-cohort, intimate mixtures of white spruce and aspen. Our goal was not to compare and contrast vegetation management tools or products, but to identify vegetation conditions that appear to favour early crop growth, such that these conditions may be recreated or emulated using one or more of the operational tools available.

As of the $10^{\text {th }}$ growing season, untended spruce plantations (BN) appear to have some potential to produce a mixedwood as a low-cost, but arguably high-risk treatment on select sites (Fig. 4). In ON, untended 10-year-old spruce averaged $185 \mathrm{~cm}$ beneath $54 \%$ cover of aspen that were nearly seven metres tall. To date, the survival and health of these spruce have been among the best observed in the study, suggesting that competition for light, physical space, and other resources have yet to reach critical levels in these plots-Biring and Hays-Byl (2000) suggest that this will occur beyond year 10 . Given the relatively low establishment costs of this strategy, it may be feasible to apply selective release treatments to the spruce before they become suppressed and begin to undergo mechanical injury from the aspen (Pitt and Bell 2005). Direct herbaceous control, as executed in this experiment $(\mathbf{B H})$, may be difficult to achieve (as experienced in $\mathrm{AB}$ ) or impractical, but any reduction of herbaceous competition that can be achieved silviculturally before or after planting may lower establishment risks, accelerate early growth of the spruce, and lead to more predictable outcomes.
The most consistently performing treatments observed across the two boreal sites were those testing our hypothesized mixedwood regeneration strategy. It was only in the $\mathbf{R W}, \mathbf{R C}_{2}$, and $\mathbf{R C}_{4}$ plots that the $\mathrm{AB}$ spruce and select aspen were on relative par with their counterparts at the ON site. The initial 50\% thinning of aspen achieved through 2-m radial treatments around spruce planted at 5-m spacing did not affect aspen height growth, but did accelerate diameter and stem volume growth on remaining trees (Table 2). Spruce performance in these plots was among the best observed in the study, particularly if they were provided with early herbaceous weed control. There is also evidence that the adjacent aspen are benefitting from this herbaceous weed control through increased stem diameter and stem volume index (Table 2). These responses are consistent with other studies that have isolated the effects of herbaceous competition (Richardson 1993, Zutter and Miller 1998, Rose et al. 1999, Wagner et al. 1999, Pitt et al. 2009). To date, however, results suggest that there is little additional benefit to control of herbaceous vegetation beyond the second year.

Through approximate equal sharing of the site's resources, the radial treatments appear to be providing aspen cover in close proximity to the spruce, offering them protection from winter freezing injury (e.g., in AB; Man et al. 2008) and late spring frost injury (e.g., in ON; Pitt et al. 2010), without reducing light availability below levels needed for good growth (Lieffers and Stadt 1994, Wright et al. 1998). Man et al. (2008), for example, reported light levels averaging $53 \%$ of open sky values in $\mathbf{R C}_{2}$ and $72 \%$ in $\mathbf{R C}_{\mathbf{4}}$ in 2005 at the $\mathrm{AB}$ site. Thus, it appears that two to four years of complete vegetation control within a $2-\mathrm{m}$ radius around spruce planted at $5-\mathrm{m}$ spacing is capable of maximizing the early performance of both spruce and aspen as a single cohort, intimate mixture. With the exception of higher-than-anticipated mortality on the spruce, this strategy appears to have the potential to provide an early rotation of aspen ( $\sim 30$ years) and a longer-term (> 60 years) sawtimber crop of spruce, as modelled by Pitt et al. (2004b). Such a strategy could conceivably be targeted at suitable microsites to mitigate the spruce mortality observed in the experiment.

\section{Operational implementation of a mixedwood strategy}

Operational means of achieving the targeted combinations of herbaceous and woody vegetation control necessary for implementing this mixedwood regeneration strategy have been discussed by Pitt et al. (2010). At the present time, there exist several ground- and air-delivered tools that are available for use in Canada, subject to provincial and local regulations. Herbicides including glyphosate, hexazinone and imazapyr, are among the most effective and efficient means of achieving herbaceous and woody vegetation control and can readily be applied to spots using backpack sprayers, or to strips using machine-mounted sprayers, ultimately achieving an initial $50 \%$ thinning of aspen, combined with herbaceous weed control for spruce establishment. Tools such as backpack-applied basal bark treatments with triclopyr and brush saws effectively remove aspen and other tall-shrub vegetation, but have the disadvantage of not controlling grass and herbaceous vegetation. Glyphosate, triclopyr and hexazinone herbicides are registered for aerial application in Canada via fixed- or rotary-winged aircraft and technology is available to produce relatively small-scale spot and strip applications with GPS 
guidance and tracking (Comeau 2012, 2014). Such applications could be made to young aspen regeneration the season prior to planting spruce.

\section{Conclusions}

Commercial demand for both spruce and aspen, coupled with increased ecological interest in restoring mixed-species ecosystems has created the need for practical, alternative regeneration strategies that will reproduce the spatial, temporal, compositional, and structural diversity of mixedwoods on boreal landscapes. This study has demonstrated the early potential of a single-cohort, intimate mixedwood regeneration strategy that involves planting white spruce at 5-m spacing (400 sph) alongside naturally regenerating aspen, given vegetation management that provides approximate equal sharing of site resources by the two species. The spatial arrangement facilitates early vegetation management treatment and aspen removal using conventional cut-to-length harvesting systems. The goal of the strategy is to produce an early technical rotation of aspen ( $\sim$ age 30$)$ and a long-term sawlog rotation of spruce (age 60 or older). By age 10, this strategy, coupled with two years of herbaceous weed control, produced spruce that had equivalent or better $(\alpha=0.05)$ survival, health and height growth than spruce grown competition-free for the duration of the experiment. Select aspen forming these mixedwoods had equivalent or better height and stem diameter than "crop trees" in undisturbed stands. While the experiment is established for rotation-length monitoring, these $10^{\text {th }}$-year results suggest that this regeneration strategy may effectively contribute to an integrated vegetation management program and we encourage operational implementation within the context of adaptive management.

\section{Acknowledgements}

We thank Daniel Chicoine, Paul Goddin, Leslie Proudfoot and Paul Weedon for their collective input to the development of the mixedwood regeneration hypothesis tested in this study. Support from the following agencies has made this research possible: Alberta Herbicide Task Force (now the Silviculture Subcommittee of the Alberta Forest Products Association); Alberta Mixedwood Management Association; Blue Ridge Lumber (1981) Ltd.; Canadian Ecology Centre Forestry Research Partnership; Canadian Forest Products Ltd.; Canadian Forest Service - Canadian Wood Fibre Centre, Great Lakes and Northern Forestry Centres; Dow AgroSciences Canada Inc.; Forest Protection Ltd.; Forestry Futures Trust Ontario; Grant Forest Products Inc.; Living Legacy Trust; Louisiana-Pacific Corp.; Millar Western Forest Products Ltd.; Millson Forestry Service; Monsanto Canada Inc.; Natural Sciences and Engineering Research Council of Canada (NSERC); Ontario Ministry of Natural Resources and Forestry; Spray Efficacy Research Group International (SERG-I); Tembec; and the University of Alberta. In addition, we are indebted to a growing list of field staff without whose care and effort this study would not be possible: Eric Boychuk, Laura Chittick, Jennifer Cross, Rob Cross, Susan Humphries, Jorma Paloniemi, Lorna Pitt, Nikki Wood, Chad Yurich and many dedicated summer students.

\section{References}

Bates, P.C., C.R. Blinn, A.A. Alm and D.A. Perala. 1989. Aspen stand development following harvest in the Lake States region. North. J. Appl. For. 6: 178-183.

Bergeron, Y., H.Y.H. Chen, N.C. Krenkel, A.L. Leduc and S.E. Macdonald. 2014. Boreal mixedwood dynamics: Ecological processes underlying multiple pathways. For. Chron. 90: 202-213.

Biring, B. and W. Hays-Byl. 2000. Ten-year conifer and vegetation responses to glyphosate treatment in the SBSdw3. B.C. Ministry of Forests, Victoria, BC. Extension Note 48, 5 p.

Boateng J. O., J.L Heineman, J. McClarnon and L. Bedford. 2006. Twenty year responses of white spruce to mechanical site preparation and early chemical release in the boreal region of northeastern British Columbia. Can. J. For. Res. 36: 2386-2399.

Burns, R.M. and B.H. Honkala. 1990. Silvics of North America: 2. Hardwoods. Agriculture Handbook 654, U.S. Dept. of Agriculture, Forest Service, Washington, D.C. vol. 2, 877 p.

Chen, H.Y.H. and R.V. Popadiouk. 2003. Dynamics of North American boreal mixedwoods. Environ. Rev. 10: 137-166.

Cogbill, C.V. 1985. Dynamics of the boreal forests of the Laurentian Highlands, Canada. Can. J. For. Res. 15:252-261.

Cole, E., A. Youngblood and M. Newton. 2003. Effects of competing vegetation on juvenile white spruce (Picea glauca (Moench) Voss) growth in Alaska. Ann. For. Sci. 60: 1-11.

Comeau, P.G. 2012. Mixedwood management for the late $21^{\text {st }}$ century-what might the future hold? Available from : http://www.ualberta.ca/ pcomeau/mixedwoods2012/ Presentations/Wed\%20June \%2020\%20Empire\%20Room\%20-20main\%20room/M.\%20 Comeau.pdf [Accessed Feb. 9, 2015]

Comeau, P.G. 2014. Effects of aerial strip spraying on mixedwood stand structure and tree growth. For Chron. 90: 479-485.

Comeau, P.G., C.N. Filipescu, R. Kabzems and C. DeLong. 2004. Early growth of white spruce underplanted beneath spaced and unspaced aspen stands in northeastern British Columbia. Can. J. For. Res. 34: 2277-2283.

Comeau, P.G., R. Kabzems, J. McClarnon and J. Heineman. 2005. Implications of selected approaches for regenerating and managing western boreal mixedwoods. For. Chron. 81(4):559-574.

Comeau, P.G., C.N. Filipescu, R. Kabzems and C. DeLong. 2009. Growth of white spruce underplanted beneath spaced and unspaced aspen stands in northeastern B.C. -10 year results. For. Ecol. Man. 257: 1087-1094.

DeLong, C. 1991. Dynamics of boreal mixedwood ecosystems. In A. Shortreid (ed.). Proc. of the Symposium on Northern Mixedwoods '89. Sept. 12-14, 1989, Fort St. John, BC. FRDA Report 164, Forestry Canada, Pacific Forestry Centre. pp. 30-31.

[ESRD] Environment and Sustainable Resource Development. 2013. Reforestation Standard for Alberta. Available from: http://esrd.alberta.ca/lands-forests/forest-management/documents/RSA-ReforestationStandard2013-Nov20-2013.pdf. [Accessed Feb. 9, 2015].

Frey, B.R., V.J. Lieffers, .S.M. Landhäusser, P.G. Comeau and K.J. Greenway. 2003. An analysis of sucker regeneration of trembling aspen. Can. J. For. Res. 33: 1169-1179.

Gradkowski, T., V.J. Lieffers, S.M. Landhäusser, D. Sidders, J. Volney and J.R. Spence. 2010. Regeneration of Populus nine years after variable retention harvest in boreal mixedwood forests. For. Ecol. Manage. 259: 383-389.

Greene, D.F., J.C. Zasada, L. Sirois, D. Kneeshaw, H. Morin, I. Charron and M.-J. Simard. 1999. A review of the regeneration dynamics of North American boreal forest tree species. Can. J. For. Res. 29: 824-839.

Groot, A. 1999. Effects of shelter and competition on the early growth of planted white spruce (Picea glauca). Can. J. For. Res. 29: 1002-1014. 
Groot, A., D.W. Carlson and J.E. Wood. 1996. Microclimatic influences of small forest openings on white spruce and trembling aspen regeneration. In C.R Smith and G.W. Crook (compilers). Advancing Boreal Mixedwood Management in Ontario. Natural Resources Canada, Canadian Forest Service, and the Ontario Ministry of Natural Resources, Sault Ste. Marie, ON. pp. 106-109.

Harvey, B.D., A. Leduc, S. Gauthier and Y. Bergeron. 2002. Standlandscape integration in natural disturbance-based management of the southern boreal forest. For. Ecol. Manage. 155: 369-385.

Kabzems, R., A.L. Nemec and C. Farnden. 2007. Growing trembling aspen and white spruce intimate mixtures: Early results (13-17 years) and future projections. BC J. Ecosystems and Manage. 8(1): 1-14. Lanner, R.M. 1985. On the sensitivity of height growth to spacing. For. Ecol. Manage. 13: 143-148.

Lieffers, V.J. and J.A. Beck Jr. 1994. A semi-natural approach to mixedwood management in the prairie provinces. For. Chron. 70(3): 260-264.

Lieffers, V.J. and K.J. Stadt. 1994. Growth of understorey Picea glauca, Calamagrostis canadensis, and Epilobium angustifolium in relation to overstorey light transmission. Can. J. For. Res. 24:1193-1198.

Liefers, V.J., R.B. MacMillan, D. MacPherson, K. Branter and J.D. Stewart. 1996. Semi-natural and intensive silviculture systems for the boreal mixedwood forest. For. Chron. 72: 286-292.

Lieffers, V.J., C. Messier, P.J. Burton, J.-C. Ruel and B.E. Grover. 2003. Nature-based silviculture for sustaining a variety of boreal forest values. In P.J. Burton, C. Messier, D. W. Smith, and W.L. Adamowicz (eds.). Towards Sustainable Management of the Boreal Forest. NRC Research Press, Ottawa, Ontario, Canada. pp. 481-530. MacDonald, B., D.M. Morris and P.L. Marshall. 1990. Assessing components of competition indices for young boreal plantations. Can. J. For. Res. 20: 1060-1068.

Man, C.D., P.G. Comeau and D.G. Pitt. 2008. Competitive effects of woody and herbaceous vegetation in a young boreal mixedwood stand. Can. J. For. Res. 38: 1817-1828.

Man, R., J.A. Rice and G.B. MacDonald. 2013. Performance of planted spruce and natural regeneration after pre- and post-harvest spraying with glyphosate and partial cutting on an Ontario (Canada) boreal mixedwood site. Forestry 84:475-480. doi:10.1093 /forestry/cpt018.

Navratil, S. 1996. Silvicultural systems for managing deciduous and mixedwood stands with a white spruce understorey. In P.G. Comeau and K.D. Thomas (eds.). Silviculture of temperate and boreal broadleaf-conifer mixtures. Province of BC, Ministry of Forests Research Program, Victoria. pp. 35-46.

Navratil, S., K. Branter and J. Zasada. 1991. Regeneration in the mixedwoods. In A. Shortreid (ed.). Proc. of the Symposium on Northern Mixedwoods '89. Sept. 12-14, 1989, Fort St. John, BC. FRDA Report 164, Forestry Canada, Pacific Forestry Centre. pp. 32-48.

Nienstadt, H. and J.C. Zasada. 1990. Picea glauca (Moench) Voss. White spruce. In R.M. Burns and B.H. Honkala (eds.). Silvics of North America. Vol. 1. Conifers. USDA Agric. Handbk. 654, pp. 204-226.

Nlungu-Kweta, P., A. Leduc and Y. Bergeron. 2014. Conifer recruitment in trembling aspen (Populus tremuloides Michx.) stands along an east-west gradient in the boreal mixedwoods of Canada. Forests 5: 2905-2928.

OMNR. 2001. Forest management guide for natural disturbance pattern emulation, Version 3.1. Ont. Min. Nat. Res., Queen's Printer for Ontario, Toronto. 40 p. Available from: https://dr6j45jk9xcmk. cloudfront.net/documents/2801/guide-natural-disturbance.pdf [Accessed Dec. 30, 2014]

Perala, D.A. 1990. Populus tremuloides Michx. Quaking aspen. In Silvics of North America. Vol. 2. Hardwoods. Edited by R.M. Burns and B.H. Honkala. USDA Agric. Handbk. 654, pp. 555-569.

Peters, V.S., S.E. MacDonald and M.R.T. Dale. 2006. Patterns of initial versus delayed regeneration of white spruce in boreal mixedwood succession. Can. J. For. Res. 36: 1597-1609.
Pitt, D.G. and F.W. Bell. 2005. Juvenile response to conifer release alternatives on aspen-white spruce boreal mixedwood sites. Part I: Stand structure and composition. For. Chron. 81(4): 538-547.

Pitt, D.G., R.G. Wagner and W.D. Towill. 2004a. Ten years of vegetation succession following ground-applied release treatments in young black spruce plantations. North. J. Appl. For. 21(3): 123-134. Pitt, D.G., M. Mihajlovich and L. Proudfoot. 2004b. Juvenile stand responses and potential outcomes of conifer release efforts on Alberta's spruce-aspen mixedwood sites. For. Chron. 80(5): 583-597. Pitt, D.G., R.A. Fleming, D.G. Thompson and E.G. Kettela. 1992. Glyphosate efficacy on eastern Canadian forest weeds. Part II: Deposit-response relationships and crop tolerance. Can. J. For. Res. 22: $1160-1171$.

Pitt, D.G., A. Morneault, W.C. Parker, A. Stinson and L. Lanteigne. 2009. The effects of herbaceous and woody competition on planted white pine in a clearcut site. For. Ecol. Man. 257: 1281-1291.

Pitt, D.G., P. G. Comeau, W. C. Parker, D. MacIsaac, S. McPherson, M.K. Hoepting, A. Stinson and M. Mihajlovich. 2010. Early vegetation control for the regeneration of a single-cohort, intimate mixture of white spruce and trembling aspen on upland boreal sites. Can. J. For. Res. 40: 549-564. doi:10.1139/X10-012.

Radvanyi, A. 1987. Snowshoe hares and forest plantations: a literature review and problem analysis. Can. For. Serv. Information Report NOR-X-290. Northern Forestry Centre. 17 pp.

Richardson, B. 1993. Vegetation management practices in plantation forests of Australia and New Zealand. Can. J. For. Res. 23: 1989-2005.

Rose, R., J.S. Ketchum and D.E. Hanson. 1999. Three-year survival and growth of Douglas-fir seedlings under various vegetation-free regimes. For. Sci. 45: 117-126.

Soil Classification Working Group 1998. The Canadian System of Soil Classification, Third Edition. Edited by R.H. Haynes. National Research Council of Canada. $187 \mathrm{p}$.

Stuart-Smith, K. 1995. Implementing ecosystem management at the stand level. In Implementing forest ecosystem management: An industrial perspective. Conf. Proc., May 29-31, 1995, Prince George, BC. pp. 38-44.

Sutton, R.F. and T.P. Weldon. 1996. White spruce establishment in boreal mixedwoods using pelleted hexazinone. In C.R. Smith and G.W. Crook (compilers). Advancing Boreal Mixedwood Management in Ontario. Natural Resources Canada, Canadian Forest Service, and the Ontario Ministry of Natural Resources, Sault Ste. Marie, ON. p. 141-143.

Wagner, R.G. 1993. Research directions to advance forest vegetation management in North America. Can. J. For. Res. 23: 2317-2327.

Wagner, R.G. and S.R. Radosevich. 1991. Neighborhood predictors of intraspecific competition in young Douglas-fir plantations. Can. J. For. Res. 21: 821-828.

Wagner, R.G., G.H. Mohammed and T.L. Noland. 1999. Critical period of interspecific competition for northern conifers associated with herbaceous vegetation. Can. J. For. Res. 29(7): 890-897.

Wood, J.E. and F.W. von Althen. 1993. Establishment of white spruce and black spruce in boreal Ontario: Effects of chemical site preparation and post-planting weed control. For. Chron. 69: 554-560.

Wright, E.F., K.D. Coates, C.D. Canham and P. Bartemucci. 1998. Species variability in growth responses to light across climatic regions in northwestern British Columbia. Can. J. For. Res. 28: 871-886.

Zutter, B.R. and J.H. Miller. 1998. Eleventh-year response of loblolly pine and competing vegetation to woody and herbaceous plant control on a Georgia flatwood site. South. J. Appl. For. 22: $85-95$. 
Tabular summarization of the treatment means plotted in Figures 3 and 4 . See Figure 1 for treatment definitions.

\begin{tabular}{|c|c|c|c|c|c|c|c|c|c|c|}
\hline \multirow[b]{2}{*}{ Site } & \multirow[b]{2}{*}{ Life Form } & \multirow[b]{2}{*}{ Variable } & \multicolumn{8}{|c|}{ Treatment } \\
\hline & & & BA & $\mathrm{BN}$ & $\mathrm{BH}$ & BW & $\overline{B C}$ & RW & $\mathbf{A C}_{2}$ & $\mathrm{RC}_{4}$ \\
\hline \multirow[t]{22}{*}{ AB } & \multirow[t]{3}{*}{ Aspen } & cover (\%) & 58 & 59 & 61 & 0 & 0 & 30 & 27 & 28 \\
\hline & & height (m) & 491 & 474 & 483 & & & 419 & 421 & 441 \\
\hline & & sph & 30570 & 35400 & 32530 & 0 & 0 & 22080 & 17240 & 16980 \\
\hline & \multirow[t]{3}{*}{ Other deciduous } & cover (\%) & 7 & 3 & 0 & 0 & 0 & 1 & 1 & 2 \\
\hline & & height (m) & 491 & 434 & & & & 245 & 250 & 301 \\
\hline & & sph & 2230 & 1500 & 0 & 0 & 0 & 1000 & 1210 & 1220 \\
\hline & \multirow[t]{2}{*}{ Planted spruce } & cover (\%) & 0 & 1 & 2 & 4 & 16 & 1 & 1 & 2 \\
\hline & & sph & 0 & 1340 & 1290 & 1260 & 1240 & 350 & 330 & 320 \\
\hline & \multirow[t]{3}{*}{ Other conifer } & cover (\%) & 0 & 0 & 0 & 0 & 0 & 0 & 0 & 0 \\
\hline & & height (m) & & & & & & & & \\
\hline & & NPH & 0 & 0 & 0 & 0 & 0 & 0 & 0 & 0 \\
\hline & \multirow[t]{2}{*}{ Tall Shrub } & cover (\%) & 11 & 9 & 1 & 0 & 0 & 4 & 6 & 5 \\
\hline & & height $(m)$ & 262 & 232 & 201 & & & 149 & 150 & 165 \\
\hline & \multirow[t]{2}{*}{ Low Shrub } & cover (\%) & 13 & 17 & 0 & 5 & 0 & 8 & 7 & 10 \\
\hline & & height (m) & 60 & 55 & & 36 & & 42 & 42 & 44 \\
\hline & \multirow[t]{2}{*}{ Fern } & cover (\%) & 0 & 0 & 0 & 0 & 0 & 0 & 0 & 0 \\
\hline & & height (m) & & & & & & & & \\
\hline & \multirow[t]{2}{*}{ Forb } & cover (\%) & 24 & 27 & 1 & 14 & 5 & 21 & 35 & 31 \\
\hline & & height (m) & 29 & 25 & 6 & 39 & 17 & 38 & 48 & 52 \\
\hline & \multirow[t]{2}{*}{ Grass/sedge } & cover (\%) & 5 & 7 & 1 & 30 & 5 & 11 & 7 & 5 \\
\hline & & height (m) & 49 & 56 & 25 & 53 & 25 & 60 & 59 & 57 \\
\hline & Total & cover (\%) & 80 & 82 & 62 & 44 & 10 & 54 & 60 & 57 \\
\hline \multirow[t]{22}{*}{ ON } & \multirow[t]{3}{*}{ Aspen } & cover (\%) & 56 & 54 & 56 & 0 & 0 & 22 & 32 & 27 \\
\hline & & height (m) & 644 & 656 & 610 & & & 421 & 526 & 483 \\
\hline & & sph & 12530 & 14370 & 11700 & 0 & 0 & 4780 & 7300 & 5590 \\
\hline & \multirow[t]{3}{*}{ Other deciduous } & cover (\%) & 1 & 1 & 0 & 0 & 0 & 0 & 0 & 0 \\
\hline & & height (m) & 153 & 181 & & & & & & \\
\hline & & sph & 770 & 730 & 0 & 0 & 0 & 0 & 0 & 0 \\
\hline & \multirow[t]{2}{*}{ Planted spruce } & cover (\%) & 0 & 7 & 13 & 7 & 12 & 2 & 3 & 4 \\
\hline & & sph & 0 & 1310 & 1200 & 1100 & 1170 & 320 & 310 & 330 \\
\hline & \multirow[t]{3}{*}{ Other conifer } & cover (\%) & 5 & 12 & 1 & 4 & 1 & 3 & 3 & 3 \\
\hline & & height (m) & 127 & 205 & 39 & 92 & 42 & 125 & 122 & 128 \\
\hline & & sph & 3230 & 3830 & 570 & 1970 & 470 & 1160 & 1160 & 1020 \\
\hline & \multirow[t]{2}{*}{ Tall Shrub } & cover (\%) & 12 & 4 & 0 & 0 & 0 & 3 & 5 & 8 \\
\hline & & height (m) & 161 & 144 & & & & 109 & 134 & 124 \\
\hline & \multirow[t]{2}{*}{ Low Shrub } & cover (\%) & 41 & 39 & 0 & 14 & 0 & 47 & 43 & 45 \\
\hline & & height (m) & 48 & 47 & & 23 & & 41 & 38 & 44 \\
\hline & Fern & cover (\%) & 12 & 12 & 0 & 3 & 0 & 30 & 13 & 11 \\
\hline & & height $(m)$ & 52 & 44 & & 47 & & 63 & 54 & 56 \\
\hline & Forb & cover (\%) & 48 & 48 & 1 & 44 & 4 & 34 & 39 & 31 \\
\hline & & height (m) & 22 & 19 & 5 & 13 & 10 & 19 & 18 & 21 \\
\hline & Grass/sedge & cover (\%) & 2 & 3 & 0 & 7 & 1 & 6 & 3 & 3 \\
\hline & & height (m) & 57 & 51 & & 20 & 13 & 38 & 35 & 16 \\
\hline & Total & cover (\%) & 92 & 90 & 56 & 63 & 5 & 82 & 81 & 77 \\
\hline
\end{tabular}

